\title{
IMPACT OF DEMOGRAPHIC VARIABLES ON INVESTMENT BEHAVIOUR OF UNIVERSITY TEACHERS
}

\section{Sudhindra Bhat}

SS Law, India

\section{Dr. Swati Sharma}

Amity University India

\section{Dr. Bert Wolfs}

SBS Swiss Business School, Zurich, Swizerland

\begin{abstract}
Investment is the application of funds to purchase assets over a short or long term for the purpose of achieving profits and or generating income from those assets. All investment decisions are made at the point of time in occurrence with the personal investment ends and in contemplation of an uncertain future. The objectives of this study were to identify the dimensions of investment decision behavior and analyze the impact of demographic variables on investment decision behavior. The study was identified seven dimensions of investment decision behavior. Age and designation are not related to investment decision behavior. Female is more perceived self-imagery than male. University teachers working in the technical department are more perceived self-imagery, self-confident and allegiance. The study results also revealed that the respondents living in the joint family are more self-responsible.
\end{abstract}

Key words: Investment decision behavior, factor analysis, demographic variables, University teachers, perceives-self imagery.

Cite this Article: Sudhindra Bhat, Swati Sharma and Bert Wolfs, Impact of Demographic Variables on Investment Behaviour of University Teachers, International Journal of Management, 11(12), 2020, pp 149-163.

http://iaeme.com/Home/issue/IJM?Volume=11\&Issue=12

\section{INTRODUCTION}

Investment is the application of funds to purchase assets over a short or long term for the purpose of achieving profits and or generating income from those assets. Investment is the sacrifice of certain present value for the uncertain future reward. It entails arriving at various decisions such as type, mix, amount, timing and grade. An investment decision is a trade-off 
between risk and returns. All investment decisions are made at the point of time in occurrence with the personal investment ends and in contemplation of an uncertain future. National saving is an important feature for achieving high growth in the economy. It is the sum of savings by public and private sector. More savings rates bring out more investment (Rehman et al. 2011). According to Odoemenem et al. (2013),saving and investment are normally considered in economics as disposable income minus consumption expenditure. It could also be regarded as income that is not consumed immediately by buying goods and services. Saving is closely related to investment and in many instances the terms saving and investment are used interchangeably (Sireesha \& Laxmi, 2013). Schumpter (2008) described that the interest to increase domestic financial institutions and patterns of behavior necessary to generate and mobilize scarce capital or saving and investment funds as key conditions for economic growth. Kasilingam \& Jayabal, (2008) identified that the investment behavior consists of why investors invest, where and how investors get information, what factors investors use to evaluate, who influences investors on the choice of investment and how they act after investment. The demographic composition of a country's population may be associated with its saving rate and investment, and may therefore, have consequences for its economic growth. One explanation for such an association is that the saving and investment rate tends to be relatively high for birth cohort when it experiences its peak earnings, and relatively low when a cohort anticipates relatively low earnings, such as during retirement. Teaching is the one of the most popular professions across the globe. Teachers are an important force in our society, not only because of their sheer numbers but much more because they are guarantors of the education of further generations, especially in the developing country like India. A teacher enjoys the privileged position of 'unleashing the human potential of students within the formal education system' and thereby transforming the individuals, families, communities and society and society at large. The quality of one's life is closely tied to the level or standard of living maintained by the person. Hence, the researcher decided to conduct a study in the impact of demographic variables on the investment behavior behavior of University teachers.

\section{REVIEW OF LITERATURE}

Job (1995) identifies the relationship between income and saving schemes of employees. The study result reveals that the savings are made to get regular in future. Profitability, liquidity, safety, tax concession, and appreciation are the main reasons for investments. Solmon (1975) found that motives for saving varied with education. Low level-educated individuals were more likely to save providing for emergencies as their primary savings goal, while those with more education cited the desire to provide for children's education and to help them set up households. Fisher (1952) revealed that age and stage of the population will affect the fraction of aggregated income spent. The old and young tend to spend a higher proportion of their incomes than those in the middle do. Bal and Bal (1982) have noted that income influencing number of demographic and other socio-economic factors such as a type of tenancy, size of family etc, and among these factors the role and type of family, number of earners and educational level of head of the family are found to be significant. The results of the study indicate that the increase in savings was relatively more for the nuclear families, average savings increased with the number of earners in the family and the level of education showed a significant effect on savings of these two years. The savings increased with the increase in the education level of the head of the farm family. According to Ashok Kumar et al. (1985) the savings -income ratio is small for a younger group, high for middle age group, and again low among old age groups. Ashok Kumar and Jagadeswara (1985) found that propensity to save and propensity to consume is also influenced by the size of the family. With an increase in family size, the propensity to consume increased due to increased demand for food, 
clothing and other necessaries of life. Women does not take active part in trading because still they make more profits and men hurt their profit by trading more and more. According to Preda (2001) women are purposefully kept away from financial decision makers because they cannot understand investment. Kiran and Rao (2005) examined the effect of demographic and psychographic variables on a risk-bearing capacity of Indian investors. The findings of the study indicate that a strong relationship between risk taking attitude and demographic and psychographic variables. Geetha and Vimala (2014) aims to conducted a study to investigated the effect of demographic variables on the investment decisions. They found that demographic factors such as age, income, education, and occupation had an influence on the investment avenue preference. Graff et al. (2008) identified that the household saving and investment decision is influenced by different demographic variables such as age, gender, education, marital status, culture, religion and dependent family size. According to Oyejide (1999) age, sex, culture, tradition, social taboos, and many more which by playing an important role determines the saving and investment behavior of any region, state or country. Rehman et al. (2011) found that lower income group age, female to male ratio, marital status insignificantly affect saving levels. Bhatt et al. (2013) study findings indicate that female are conservative and male members are aggressive while investing. There is no significant relationship between marital status and the investment choice made by the investor. Individual characteristics such as age, gender, marital status, and lifestyle determined the savings and investment behavior (Achar, 2012). Panda and Panda (2013) found that family size, annual income, and annual savings have a significant relationship between investments made by the respondents, whereas gender, age, education, and occupation have no significant relationship with the period of investments made by the investors. Demographic variables such as age, gender, education, occupation play a key role in investment decision (Jain \& Mandot, 2012; Jamshidinarid et al, 2012; Geetha \& Ramesh, 2011). Bishoni (2014) conducted a survey of 400 investors to identify the relationship between demographic variables of any investment objectives preferred by investors. The study results revealed that all demographic factors have a significant association with an investment objective. Dhiraj and Nikhil (2012) investigated the investment decisions of individuals with demographic variables. They found, there was a positive correlation between knowledge, income level of investors of different cities and there was no significant relationship between gender on investment decision.

\section{SIGNIFICANCE OF THE STUDY}

Teachers those who are at school level or college level or university level play a key role in the life of every student. Teachers act as laying steps for creating responsible citizens and good human beings. They are the cornerstone of our future. Teachers may not be an expert on finances and unable to assist their own financial situation to develop and grow over time. They may have limited financial knowledge that hinders them from making the most of their earnings to build a secure nest egg for a comfortable retirement. Despite their high level of intelligence and an educated background, it is not uncommon for teachers to lack the financial skills and knowledge they need to make the most of their situation whilst they are still working to ensure a worry-free retirement.

\section{OBJECTIVES OF THE STUDY}

The following is the objectives of the research

1.To identify the dimensions of investment decision behavior

2.To analyze the relationship between demographic variables and dimensions of investment decision behavior. 


\section{RESEARCH HYPOTHESIS}

Ho: There is no significant relationship between demographic variables and dimensions of investment decision behavior

\section{RESEARCH METHODOLOGY}

Primary data was used to analyze the relationship between the investment decision behavior and demographic variables. The primary data was collected by using structured questionnaire from University teachers of Karnataka and Rajasthan. For the purpose of the study 200 respondents from Government Universities, 200 respondents from Deemed Universities and 300 respondents from Private Universities. Totally 700 samples were collected by using a stratified sampling method. The data were analyzed by using statistical tools like factor analysis, ANOVA and t-test.

\section{RESULTS AND DISCUSSIONS}

\subsection{Factor Analysis for Investment Decision Behaviour}

Factor analysis was carried out for Investment decisions in which 23 statements relating to Investment decisions were factor analysed to identify the dimensions that explain the variance. For this purpose principal component analysis method was used with orthogonal varimax rotation. From the varimax rotated factors matrix, Seven factors were identified with Eigen values $>1$ that explains $83.501 \%$ of the variance, from the original 23 variables. As a result, 4 statements were deleted from the analysis. Seven investment decisions factors with 19 variables, were defined by the original 23 variables, that were loaded most heavily (loading $>0.5$ ) on them. The results of varimax rotation yielded an apparent factor structure that had higher loadings, on suitable factors. The variables with high loadings indicate a correlation of the variables, with the factors, on which, they were loaded. The Reliability analysis and internal consistency of identified factors were verified using Cronbach se Alpha. Suggestions of Fornell and Larcker (1981) were employed to evaluate scale reliability. The results showed that the alpha coefficient for the 7 factors ranged from 0.564 to 0.954 , well above the minimum value of 0.5 considered acceptable, which is indicative of reliability of the research.

Sampling adequacy measure of 0.636 is mediocre as per guidelines (Heir et al, 2003). Bartlettes test of sphericity yielded a chi-square value of 11440.960 at 190 degrees of freedom and 0.000 significance level that clearly demonstrates that the factors were related. The factors were given appropriate names based on the nature and loading observed on specific factors.

Table 1 Factor Analysis for Investment decision behaviour

\begin{tabular}{|c|c|c|c|c|}
\hline & $\begin{array}{l}\text { Factor } \\
\text { Load }\end{array}$ & $\begin{array}{l}\text { Eigen } \\
\text { Value }\end{array}$ & $\%$ of variance & Cronbach alpha \\
\hline $\begin{array}{l}\text { Factor 1: Perceived Self-Imagery } \\
\text { My risk appetite is high } \\
\text { I feel I am good in investment decision } \\
\text { I make investment decision on my own } \\
\text { My investment gives me satisfactory returns }\end{array}$ & $\begin{array}{l}0.941 \\
0.937 \\
0.935 \\
0.907\end{array}$ & 4.119 & 20.595 & 0.954 \\
\hline $\begin{array}{l}\text { Factor 2: Self-confidence } \\
\text { I am confident of my ability to select financial instruments for } \\
\text { investment } \\
\text { Good investment opportunities induce me for making investment. } \\
\text { Advisors can handle my investment better } \\
\text { My investment decision has changed over period of time }\end{array}$ & $\begin{array}{l}0.921 \\
0.903 \\
0.883 \\
0.842\end{array}$ & 3.554 & 17.772 & 0.916 \\
\hline
\end{tabular}




\begin{tabular}{|c|c|c|c|c|}
\hline $\begin{array}{l}\text { Factor } 3: \text { Allegiance } \\
\text { I consult my family members before taking investment decision } \\
\text { I take decision on saving/investment after getting full information } \\
\text { Investment decision will have impact on lifestyle of a person }\end{array}$ & $\begin{array}{l}0.940 \\
0.910 \\
0.894\end{array}$ & 2.708 & 13.538 & 0.916 \\
\hline $\begin{array}{l}\text { Factor 4: Financial Inadequacy } \\
\text { Financial advisors will help me save more on tax } \\
\text { I save more when the interest rate is more } \\
\text { I do not take intuitive investment decisions }\end{array}$ & $\begin{array}{l}0.926 \\
0.914 \\
0.888\end{array}$ & 2.337 & 11.684 & 0.908 \\
\hline $\begin{array}{l}\text { Factor 5: Risk Aversion } \\
\text { I am getting good return because I have taken calculated } \\
\text { decision } \\
\text { I prefer investment with minimum returns, maximum capital } \\
\text { protection }\end{array}$ & 0.945 & 1.522 & 7.612 & 0.933 \\
\hline $\begin{array}{l}\text { Factor 6: Prudence } \\
\text { To me thrill is essential while making investment. } \\
\text { I review my investment decision frequently }\end{array}$ & $\begin{array}{l}0.805 \\
0.780\end{array}$ & 1.368 & 6.838 & 0.564 \\
\hline $\begin{array}{l}\text { Factor 7: Self-responsible } \\
\text { I take full responsibility for the result of my investment } \\
\text { decisions }\end{array}$ & 0.952 & 1.092 & 5.462 & \\
\hline
\end{tabular}

The above table indicates the factor analysis based on investment decision behavior statements. The 7 factors were named as perceived self-imagery, self-confidence, allegiance, financial inadequacy, risk aversion, prudence and self-responsible

Factor 1: Perceived Self-Imagery: This factor reflects the perceived self-imagery of the university teachers. High scores on this factor can be characterised that, university teachers risk appetite is high, they are good in investment decisions. They make investment decisions on their own, their investment gives satisfactory returns and they have taken calculated decisions. An alpha of 0.954 indicates that this scale is reliable. This factor accounts for 20.595 per cent of the variance and Eigen value of 4.119 and may be named as "Perceived Self-Imagery".

Factor 2: Self-confidence: This factor measures the self-confidence of the respondents. Those scoring high on this factor are confident of their ability to select financial instruments for investment. Good investment opportunities induce them for making investments; their investment decision has changed over period of time. An alpha of 0.916 indicates that this scale is reliable. This factor explains 17.772 per cent of variance and Eigen value of 3.554 and may be named as "Self-confidence".

Factor 3: Allegiance: This factor reflects the allegiance of the respondents. Those scoring high on this factor feel that they consult my family members before taking investment decision. They take decision on saving/investment after getting full information and Investment decision will have an impact on the lifecycle of a person. An alpha of 0.916 indicates that, this scale is reliable. This factor explains 13.538 percent of variance and Eigen value of 2.708 and may be named as "Allegiance".

Factor 4: Financial Inadequacy: This factor reflects the financial inadequacy of the respondents. Those scoring high on this factor, rely on financial advisors to help them save more on tax, they save more when the interest rate is more and they do not take intuitive investment decisions. An alpha of 0.908 indicates that this scale is reliable. This factor explains 11.684 percent of variance and Eigen value of 2.337 and may be named as "Financial Inadequacy". 
Factor 5: Risk Aversion: This factor reflects the risk aversion of the respondents. Those scoring high on this factor feel that they are getting good return because they have taken calculated decision and prefer investment with minimum returns and maximum capital protection. An alpha of 0.933 indicates that this scale is reliable. This factor explains 7.612 percent of variance and Eigen value of 1.5223 and may be named as "Risk Aversion".

Factor 6: Prudence: This factor reflects the prudence of the respondents. Those scoring high on this factor are feeling that thrill is essential while making investment to them. They review investment decision frequently. An alpha of 0.564 indicates that, this scale is reliable. This factor explains 6.838 percent of variance and Eigen value of 1.368 and may be named as "Prudence".

Factor 7: Self-responsible: This factor reflects the prudence of the respondents. Those scoring high on this factor are taken full responsibility for the result of my investment decisions. This factor explains 5.462 percent of variance and Eigen value of 1.092 and may be named as "Self responsible".

\subsection{ANOVA AND T- TEST}

To test the relationship between demographic variables and investment decision behavior ANOVA and t-test are used.

\subsubsection{Age and Investment Decision Behaviour of the Respondents}

To find out whether there exist any significant difference in age group with the investment decision behaviour of the respondents the following hypothesis is framed and tested

Hypothesis 1: There is no significant difference between age group with respect to investment decision behaviour of the respondents.

Table 2 Age with respect to investment decision behavior

\begin{tabular}{|c|c|c|c|c|c|c|}
\hline Factors & Age Group & $\mathbf{N}$ & Mean & Df & $\mathbf{F}$ & Sig \\
\hline $\begin{array}{l}\text { Perceived Self- } \\
\text { Imagery }\end{array}$ & $\begin{array}{c}\text { 26-35 Years } \\
36-45 \text { Years } \\
46-55 \text { Years } \\
\text { Above } 55 \text { Years }\end{array}$ & $\begin{array}{c}349 \\
203 \\
133 \\
15\end{array}$ & $\begin{array}{l}2.7092 \\
2.7783 \\
2.7763 \\
3.0167 \\
\end{array}$ & 699 & 0.338 & 0.798 \\
\hline Self-confident & $\begin{array}{c}\text { 26-35 Years } \\
\text { 36-45 Years } \\
\text { 46-55 Years } \\
\text { Above } 55 \text { Years }\end{array}$ & $\begin{array}{c}349 \\
203 \\
133 \\
15 \\
\end{array}$ & $\begin{array}{l}3.6676 \\
3.5874 \\
3.6898 \\
3.7500 \\
\end{array}$ & 699 & 0.312 & 0.817 \\
\hline Allegiance & $\begin{array}{c}\text { 26-35 Years } \\
\text { 36-45 Years } \\
\text { 46-55 Years } \\
\text { Above } 55 \text { Years }\end{array}$ & $\begin{array}{c}349 \\
203 \\
133 \\
15 \\
\end{array}$ & $\begin{array}{l}3.3391 \\
3.3924 \\
3.4311 \\
3.9111 \\
\end{array}$ & 699 & 1.009 & 0.388 \\
\hline Financial Adequacy & $\begin{array}{c}\text { 26-35 Years } \\
\text { 36-45 Years } \\
46-55 \text { Years } \\
\text { Above } 55 \text { Years }\end{array}$ & $\begin{array}{c}349 \\
203 \\
133 \\
15 \\
\end{array}$ & $\begin{array}{l}3.7402 \\
3.7044 \\
3.7243 \\
3.9556 \\
\end{array}$ & 699 & 0.221 & 0.882 \\
\hline Risk Aversion & $\begin{array}{c}\text { 26-35 Years } \\
\text { 36-45 Years } \\
\text { 46-55 Years } \\
\text { Above } 55 \text { Years }\end{array}$ & $\begin{array}{c}349 \\
203 \\
133 \\
15 \\
\end{array}$ & $\begin{array}{l}3.5330 \\
3.5049 \\
3.6090 \\
3.5333 \\
\end{array}$ & 699 & 0.170 & 0.916 \\
\hline Prudence & $\begin{array}{c}26-35 \text { Years } \\
\text { 36-45 Years } \\
46-55 \text { Years } \\
\text { Above } 55 \text { Years }\end{array}$ & $\begin{array}{c}349 \\
203 \\
133 \\
15 \\
\end{array}$ & $\begin{array}{l}3.8983 \\
3.8153 \\
3.8684 \\
4.0000 \\
\end{array}$ & 699 & 0.368 & 0.776 \\
\hline Self-responsible & $\begin{array}{c}26-35 \text { Years } \\
36-45 \text { Years } \\
46-55 \text { Years } \\
\text { Above } 55 \text { Years }\end{array}$ & $\begin{array}{c}349 \\
203 \\
133 \\
15 \\
\end{array}$ & $\begin{array}{l}4.1060 \\
4.1675 \\
4.2406 \\
4.3333 \\
\end{array}$ & 699 & 0.571 & 0.634 \\
\hline
\end{tabular}


The above table shows the difference in the investment behaviour based on the age group of the respondents. There is a no significant difference in the investment behavior based on the age group of the respondents at 0.05 level of significance. All the investment behavior factors are not significant based on age of the respondents. Perceived Self -Imagery $(\mathrm{F}=$ $0.338 ; p>0.05)$, Self-confident $(F=0.312 ; p>0.05)$, Allegiance $(F=1.009 ; p>0.05)$, Financial Inadequacy $(F=0.221 ; p>0.05)$, Risk Aversion $(F=0.170 ; p>0.05)$, Prudence $(F=0.170$; $\mathrm{p}>0.05)$ and Self-responsible $(\mathrm{F}=0.368 ; \mathrm{p}>0.05)$. Hence, the null hypothesis is accepted. It is inferred that investment behavior does not differs based on the age group of the respondents.

\subsubsection{Designation and Investment Decision Behaviour of the Respondents}

To find out whether there exists any significant difference in designation with the investment decision behaviour of the respondents the following hypothesis is framed and tested

Hypothesis 2: There is no significant difference between designation with respect to investment decision behaviour of the respondents.

Table 3 Designation with respect to investment decision behavior

\begin{tabular}{|c|c|c|c|c|c|c|}
\hline Factors & Designation & $\mathbf{N}$ & Mean & Df & $\mathbf{F}$ & Sig \\
\hline $\begin{array}{l}\text { Perceived Self- } \\
\text { Imagery }\end{array}$ & $\begin{array}{l}\text { Assistant Professor } \\
\text { Associate Professor } \\
\text { Professor }\end{array}$ & $\begin{array}{l}233 \\
176 \\
291 \\
\end{array}$ & $\begin{array}{r}2.7146 \\
2.7599 \\
2.7689\end{array}$ & 699 & 0.110 & 0.896 \\
\hline Self-confident & $\begin{array}{l}\text { Assistant Professor } \\
\text { Associate Professor } \\
\text { Professor }\end{array}$ & $\begin{array}{l}233 \\
176 \\
291 \\
\end{array}$ & $\begin{array}{r}3.6255 \\
3.6761 \\
3.6546 \\
\end{array}$ & 699 & 0.098 & 0.906 \\
\hline Allegiance & $\begin{array}{l}\text { Assistant Professor } \\
\text { Associate Professor } \\
\text { Professor }\end{array}$ & $\begin{array}{l}233 \\
176 \\
291 \\
\end{array}$ & $\begin{array}{r}3.3290 \\
3.4792 \\
3.3711 \\
\end{array}$ & 699 & 0.685 & 0.505 \\
\hline $\begin{array}{l}\text { Financial } \\
\text { Adequacy }\end{array}$ & $\begin{array}{l}\text { Assistant Professor } \\
\text { Associate Professor } \\
\text { Professor }\end{array}$ & $\begin{array}{l}233 \\
176 \\
291 \\
\end{array}$ & $\begin{array}{r}3.7525 \\
3.6610 \\
3.7572 \\
\end{array}$ & 699 & 0.416 & 0.660 \\
\hline Risk Aversion & $\begin{array}{l}\text { Assistant Professor } \\
\text { Associate Professor } \\
\text { Professor }\end{array}$ & $\begin{array}{l}233 \\
176 \\
291 \\
\end{array}$ & $\begin{array}{l}3.5773 \\
3.4943 \\
3.5361\end{array}$ & 699 & 0.197 & 0.821 \\
\hline Prudence & $\begin{array}{l}\text { Assistant Professor } \\
\text { Associate Professor } \\
\text { Professor }\end{array}$ & $\begin{array}{l}233 \\
176 \\
291 \\
\end{array}$ & $\begin{array}{l}3.8734 \\
3.8580 \\
3.8763\end{array}$ & 699 & 0.019 & 0.981 \\
\hline Self-responsible & $\begin{array}{l}\text { Assistant Professor } \\
\text { Associate Professor } \\
\text { Professor }\end{array}$ & $\begin{array}{l}233 \\
176 \\
291 \\
\end{array}$ & $\begin{array}{r}4.1116 \\
4.1648 \\
4.1821 \\
\end{array}$ & 699 & 0.247 & 0.781 \\
\hline
\end{tabular}

The above table shows the difference in the investment behaviour based on the designation of the respondents. There is a no significant difference in the investment behavior based on the designation of the respondents at 0.05 level of significance. All the investment behavior factors are not significant based on designation of the respondents. Perceived Self - 
Imagery $(\mathrm{F}=0.110 ; \mathrm{p}>0.05)$, Self-confident $(\mathrm{F}=0.098 ; \mathrm{p}>0.05)$, Allegiance $(\mathrm{F}=0.685$; $\mathrm{p}>0.05)$, Financial Inadequacy $(\mathrm{F}=0.416 ; \mathrm{p}>0.05)$, Risk Aversion $(\mathrm{F}=0.197 ; \mathrm{p}>0.05)$, Prudence $(F=0.019 ; p>0.05)$ and Self-responsible $(F=0.247 ; p>0.05)$. Hence, the null hypothesis is accepted. It is inferred that investment behavior does not differs based on the designation of the respondents.

\subsubsection{Income and Investment Decision Behaviour of the Respondents}

To find out whether there exist any significant difference in income with the investment decision behaviour of the respondents the following hypothesis is framed and tested

Hypothesis 3 : There is no significant difference between income with respect to investment decision behaviour of the respondents.

Table 4 Income with respect to investment decision behavior

\begin{tabular}{|c|c|c|c|c|c|c|}
\hline Factors & Income (Annual) & $\mathbf{N}$ & Mean & Df & $\mathbf{F}$ & Sig \\
\hline $\begin{array}{l}\text { Perceived Self- } \\
\text { Imagery }\end{array}$ & $\begin{array}{l}<\text { Rs. } 5,00,000 \\
\text { Rs. } 5,00,000-\text { Rs. } 10,00,000 \\
\text { Rs } 10,00,001-\text { Rs. } 15,00,000 \\
\text { Rs. } 15,00,001-\text { Rs. } 20,00, \\
000 \\
\text { Above Rs. } 20,00,000\end{array}$ & $\begin{array}{c}56 \\
118 \\
192 \\
114 \\
\\
220 \\
\end{array}$ & $\begin{array}{l}2.8304 \\
2.9047 \\
2.6706 \\
2.8202 \\
\\
2.6750 \\
\end{array}$ & 699 & 0.827 & 0.508 \\
\hline Self-confident & $\begin{array}{l}<\text { Rs. } 5,00,000 \\
\text { Rs. 5,00,000 - Rs. } 10,00,000 \\
\text { Rs10,00,001 - Rs. } 15,00,000 \\
\text { Rs. } 15,00,001 \text { - Rs. 20,00, } \\
000 \\
\text { Above Rs.20, 00,000 }\end{array}$ & $\begin{array}{c}56 \\
118 \\
192 \\
114 \\
\\
220 \\
\end{array}$ & $\begin{array}{l}3.6741 \\
3.7013 \\
3.5742 \\
3.7105 \\
\\
3.6523 \\
\end{array}$ & 699 & 0.345 & 0.848 \\
\hline Allegiance & $\begin{array}{l}<\text { Rs. } 5,00,000 \\
\text { Rs. 5,00,000 - Rs. } 10,00,000 \\
\text { Rs10,00,001 - Rs. } 15,00,000 \\
\text { Rs. } 15,00,001 \text { - Rs. } 20,00, \\
000 \\
\text { Above Rs.20, 00,000 }\end{array}$ & $\begin{array}{c}56 \\
118 \\
192 \\
\\
114 \\
\\
220\end{array}$ & $\begin{array}{l}3.4464 \\
3.3983 \\
3.4809 \\
3.1959 \\
3.3742\end{array}$ & 699 & 0.891 & 0.469 \\
\hline Financial Adequacy & $\begin{array}{l}<\text { Rs. } 5,00,000 \\
\text { Rs. 5,00,000 - Rs. } 10,00,000 \\
\text { Rs10,00,001 - Rs. } 15,00,000 \\
\text { Rs. } 15,00,001 \text { - Rs. 20,00, } \\
000 \\
\text { Above Rs.20, 00,000 }\end{array}$ & $\begin{array}{c}56 \\
118 \\
192 \\
114 \\
220 \\
\end{array}$ & $\begin{array}{l}3.7619 \\
3.6328 \\
3.9531 \\
\\
3.5673 \\
\\
3.6682\end{array}$ & 699 & 2.624 & 0.034 \\
\hline Risk Aversion & $\begin{array}{l}<\text { Rs. } 5,00,000 \\
\text { Rs. } 5,00,000-\text { Rs. } 10,00,000 \\
\text { Rs } 10,00,001-\text { Rs. } 15,00,000 \\
\text { Rs. } 15,00,001-\text { Rs. } 20,00, \\
000 \\
\text { Above Rs. } 20,00,000\end{array}$ & $\begin{array}{c}56 \\
118 \\
192 \\
114 \\
\\
220 \\
\end{array}$ & $\begin{array}{l}3.4375 \\
3.7076 \\
3.4323 \\
3.3596 \\
\\
3.6614\end{array}$ & 699 & 1.872 & 0.114 \\
\hline Prudence & $\begin{array}{l}<\text { Rs. } 5,00,000 \\
\text { Rs. } 5,00,000-\text { Rs. } 10,00,000 \\
\text { Rs } 10,00,001-\text { Rs. } 15,00,000 \\
\text { Rs. } 15,00,001-\text { Rs. } 20,00, \\
000 \\
\text { Above Rs. } 20,00,000\end{array}$ & $\begin{array}{c}56 \\
118 \\
\\
192 \\
114\end{array}$ & $\begin{array}{l}3.7411 \\
3.8686 \\
\\
3.9401 \\
\\
3.7412\end{array}$ & 699 & 1.006 & 0.404 \\
\hline
\end{tabular}




\begin{tabular}{|l|l|c|c|c|c|c|}
\hline & & 220 & 3.9114 & & & \\
\hline Self-responsible & < Rs.5,00,000 & 56 & 4.0893 & 699 & 0.352 & 0.842 \\
& Rs. 5,00,000 - Rs. 10,00,000 & 118 & 4.1780 & & & \\
& Rs10,00,001 - Rs. 15,00,000 & & & & \\
& Rs. 15, 00,001 - Rs. 20,00, & 192 & 4.1719 & & \\
& 000 & 114 & 4.0526 & & & \\
& Above Rs.20,00,000 & 220 & 4.1955 & & & \\
& & & & & & \\
\hline
\end{tabular}

The above table shows the difference in the investment behaviour based on the income of the respondents. There is a significant difference in the Investment behaviour (financial adequacy $(\mathrm{F}=2.624 ; \mathrm{p}<0.05)$ based on the income of the respondents at 0.05 level of significance. Remaining six investment behavior factors are not significant based on income of the respondents. Perceived Self -Imagery $(F=0.827 ; p>0.05)$, Self-confident $(F=0.345$; $\mathrm{p}>0.05)$, Allegiance $(\mathrm{F}=0.891 ; \mathrm{p}>0.05)$, Risk Aversion $(\mathrm{F}=1.872 ; \mathrm{p}>0.05)$, Prudence $(\mathrm{F}=$ $1.006 ; \mathrm{p}>0.05)$ and Self-responsible $(\mathrm{F}=0.352 ; \mathrm{p}>0.05)$. Hence, the null hypothesis is rejected. It is inferred that investment behavior differs based on the designation of the respondents.

\subsubsection{Family Size and Investment Decision Behaviour of the Respondents}

To find out whether there exist any significant differences in family size with the investment decision behaviour of the respondents the following hypothesis is framed and tested

Hypothesis 4: There is no significant difference between family size with respect to investment decision behaviour of the respondents.

Table 5 Family Size with respect to investment decision behavior

\begin{tabular}{|c|c|c|c|c|c|c|}
\hline Factors & Family Size & $\mathbf{N}$ & Mean & Df & $\mathbf{F}$ & Sig \\
\hline $\begin{array}{l}\text { Perceived Self- } \\
\text { Imagery }\end{array}$ & $\begin{array}{l}2-4 \text { members } \\
5-7 \text { members } \\
\text { More than } 7 \text { members }\end{array}$ & $\begin{array}{l}582 \\
103 \\
15\end{array}$ & $\begin{array}{l}2.7496 \\
2.6845 \\
\\
3.1500\end{array}$ & 699 & 0.759 & 0.468 \\
\hline Self-confident & $\begin{array}{l}2-4 \text { members } \\
5-7 \text { members } \\
\text { More than } 7 \text { members }\end{array}$ & $\begin{array}{l}582 \\
103 \\
15 \\
\end{array}$ & $\begin{array}{l}3.6619 \\
3.6141 \\
\\
3.4500 \\
\end{array}$ & 699 & 0.302 & 0.739 \\
\hline Allegiance & $\begin{array}{l}2-4 \text { members } \\
5-7 \text { members } \\
\text { More than } 7 \text { members }\end{array}$ & $\begin{array}{l}582 \\
103 \\
15 \\
\end{array}$ & $\begin{array}{l}3.3780 \\
3.4498 \\
\\
3.1778 \\
\end{array}$ & 699 & 0.322 & 0.725 \\
\hline Financial Adequacy & $\begin{array}{l}2-4 \text { members } \\
5-7 \text { members } \\
\text { More than } 7 \text { members }\end{array}$ & $\begin{array}{l}582 \\
103 \\
15 \\
\end{array}$ & $\begin{array}{l}3.7125 \\
3.9256 \\
\\
3.1333 \\
\end{array}$ & 699 & 3.393 & 0.034 \\
\hline Risk Aversion & $\begin{array}{l}2-4 \text { members } \\
5-7 \text { members } \\
\text { More than } 7 \text { members }\end{array}$ & $\begin{array}{l}582 \\
103 \\
15\end{array}$ & $\begin{array}{l}3.5215 \\
3.6602 \\
\\
3.4000\end{array}$ & 699 & 0.564 & 0.569 \\
\hline Prudence & $\begin{array}{l}2-4 \text { members } \\
5-7 \text { members } \\
\text { More than } 7 \text { members }\end{array}$ & $\begin{array}{l}582 \\
103 \\
15 \\
\end{array}$ & $\begin{array}{l}3.8823 \\
3.8301 \\
\\
3.7000 \\
\end{array}$ & 699 & 0.332 & 0.717 \\
\hline Self-responsible & $\begin{array}{l}2-4 \text { members } \\
5-7 \text { members } \\
\text { More than } 7 \text { members }\end{array}$ & $\begin{array}{l}582 \\
103 \\
15 \\
\end{array}$ & $\begin{array}{l}4.1289 \\
4.2913 \\
\\
4.2000 \\
\end{array}$ & 699 & 0.865 & 0.422 \\
\hline
\end{tabular}

The above table shows the difference in the investment behaviour based on the family size of the respondents. There is a significant difference in the Investment behaviour (financial 
adequacy $(\mathrm{F}=3.393 ; \mathrm{p}<0.05)$ based on the family size of the respondents at 0.05 level of significance. Remaining six investment behavior factors are not significant based on family size of the respondents. Perceived Self -Imagery $(\mathrm{F}=0.759 ; \mathrm{p}>0.05)$, Self-confident $(\mathrm{F}=0.302 ; \mathrm{p}>0.05)$, Allegiance $(\mathrm{F}=0.322 ; \mathrm{p}>0.05)$, Risk Aversion $(\mathrm{F}=0.564 ; \mathrm{p}>0.05)$, Prudence $(\mathrm{F}=0.332 ; \mathrm{p}>0.05)$ and Self-responsible $(\mathrm{F}=0.865 ; \mathrm{p}>0.05)$. Hence, the null hypothesis is rejected. It is inferred that investment behavior differs based on the family size of the respondents.

\subsubsection{Gender and Investment Decision Behaviour of the Respondents}

To ascertain whether there exists any significant difference in gender with the investment decision behaviour of the respondents the following hypothesis is framed and tested.

Hypothesis 5: There is no significant difference between gender and investment decision behaviour of the respondents

Table 6 Gender with respect to investment decision behaviour

\begin{tabular}{|c|c|c|c|c|c|c|c|}
\hline Factors & Gender & $\mathbf{N}$ & Mean & $\begin{array}{c}\text { Std. } \\
\text { Deviation }\end{array}$ & Df & t- value & $\begin{array}{l}\text { Sig. (2- } \\
\text { tailed) }\end{array}$ \\
\hline $\begin{array}{l}\text { Perceived Self- } \\
\text { Imagery }\end{array}$ & $\begin{array}{l}\text { Male } \\
\text { Female }\end{array}$ & $\begin{array}{l}398 \\
302\end{array}$ & $\begin{array}{l}2.4912 \\
3.0877\end{array}$ & $\begin{array}{l}1.35274 \\
1.31380\end{array}$ & 698 & -5.851 & 0.000 \\
\hline Self-confident & $\begin{array}{l}\text { Male } \\
\text { Female }\end{array}$ & $\begin{array}{l}398 \\
302\end{array}$ & $\begin{array}{l}3.6558 \\
3.6432\end{array}$ & $\begin{array}{l}1.23291 \\
1.06045\end{array}$ & 698 & 0.142 & 0.887 \\
\hline Allegiance & $\begin{array}{l}\text { Male } \\
\text { Female }\end{array}$ & $\begin{array}{l}398 \\
302\end{array}$ & $\begin{array}{l}3.3961 \\
3.3687 \\
\end{array}$ & $\begin{array}{l}1.34304 \\
1.26260 \\
\end{array}$ & 698 & 0.275 & 0.783 \\
\hline $\begin{array}{l}\text { Financial } \\
\text { Inadequacy }\end{array}$ & $\begin{array}{l}\text { Male } \\
\text { Female }\end{array}$ & $\begin{array}{l}398 \\
302\end{array}$ & $\begin{array}{l}3.8518 \\
3.5728\end{array}$ & $\begin{array}{l}1.16511 \\
1.19292 \\
\end{array}$ & 698 & 3.105 & 0.002 \\
\hline Risk Aversion & $\begin{array}{l}\text { Male } \\
\text { Female }\end{array}$ & $\begin{array}{l}398 \\
302\end{array}$ & $\begin{array}{l}3.5113 \\
3.5762\end{array}$ & $\begin{array}{l}1.41395 \\
1.19904\end{array}$ & 698 & -0.641 & 0.522 \\
\hline Prudence & $\begin{array}{l}\text { Male } \\
\text { Female }\end{array}$ & $\begin{array}{l}398 \\
302\end{array}$ & $\begin{array}{l}3.9435 \\
3.7748\end{array}$ & $\begin{array}{l}0.99429 \\
1.03460\end{array}$ & 698 & 2.184 & 0.029 \\
\hline $\begin{array}{l}\text { Self- } \\
\text { responsible }\end{array}$ & $\begin{array}{l}\text { Male } \\
\text { Female }\end{array}$ & $\begin{array}{l}398 \\
302\end{array}$ & $\begin{array}{l}4.1859 \\
4.1126 \\
\end{array}$ & $\begin{array}{l}1.13812 \\
1.19547 \\
\end{array}$ & 698 & 0.826 & 0.409 \\
\hline
\end{tabular}

The above table indicates that $t$ - test for gender with investment behaviour of the respondents.

Gender with Perceived Self-Imagery: The t-value is -5.851 , degree of freedom 698 and two-tailed significance is 0.000 . The two-tailed significance for perceived self-imagery indicates that $\mathrm{p}<0.05$ and is significant. Therefore, we reject the null hypothesis and accept the alternative hypothesis. Hence, it is concluded that there is significant difference between male and female perceived self-imagery.

Gender with Self-confident: The t-value is 0.142 , degree of freedom 698 and two-tailed significance is 0.887 . The two-tailed significance for self-confident indicates that $p>0.05$ and is not significant. Therefore, we accept the null hypothesis and reject the alternative hypothesis. Hence, it is concluded that there is no significant difference between male and female self-confident.

Gender with Allegiance: The t-value is 0.275 , degree of freedom 698 and two-tailed significance is 0.783 . The two-tailed significance for allegiance indicates that $p>0.05$ and is not significant. Therefore, we accept the null hypothesis and reject the alternative hypothesis. Hence, it is concluded that there is no significant difference between male and female allegiance.

Gender with Financial Inadequacy: The t-value is 3.105, degree of freedom 698 and twotailed significance is 0.002 . The two-tailed significance for financial inadequacy indicates that $\mathrm{p}<0.05$ and is significant. Therefore, we reject the null hypothesis and accept the alternative 
hypothesis. Hence, it is concluded that there is significant difference between male and female financial inadequacy.

Gender with Risk Aversion: The t-value is -0.641, degree of freedom 698 and two-tailed significance is 0.522 . The two-tailed significance for risk aversion indicates that $p>0.05$ and is not significant. Therefore, we accept the null hypothesis and reject the alternative hypothesis. Hence, it is concluded that there is no significant difference between male and female risk aversion.

Gender with Prudence: The t-value is 2.184, degree of freedom 698 and two-tailed significance is 0.029 . The two-tailed significance for prudence indicates that $p<0.05$ and is significant. Therefore, we reject the null hypothesis and accept the alternative hypothesis. Hence, it is concluded that there is significant difference between male and female prudence.

Gender with Self-responsible: The t-value is 0.826 , degree of freedom 698 and two-tailed significance is 0.409 . The two-tailed significance for perceived self-responsible indicates that $\mathrm{p}>0.05$ and is not significant. Therefore, we accept the null hypothesis and reject the alternative hypothesis. Hence, it is concluded that there is no significant difference between male and female self-responsible.

\subsubsection{Department and Investment Decision Behaviour of the Respondents}

To ascertain whether there exists any significant difference in department with the investment decision behaviour of the respondents the following hypothesis is framed and tested.

Hypothesis 6: There is no significant difference between department and investment decision behaviour of the respondents

Table 7 Department with respect to investment decision behaviour

\begin{tabular}{|c|c|c|c|c|c|c|c|}
\hline Factors & Department & $\mathbf{N}$ & Mean & $\begin{array}{c}\text { Std. } \\
\text { Deviation }\end{array}$ & Df & t- value & $\begin{array}{l}\text { Sig. (2- } \\
\text { tailed) }\end{array}$ \\
\hline $\begin{array}{l}\text { Perceived } \\
\text { Self-Imagery }\end{array}$ & $\begin{array}{l}\text { Technical } \\
\text { Non- } \\
\text { technical }\end{array}$ & $\begin{array}{l}379 \\
321\end{array}$ & $\begin{array}{l}2.7751 \\
2.7173\end{array}$ & $\begin{array}{l}1.35084 \\
1.38832\end{array}$ & 698 & 0.557 & 0.558 \\
\hline Self-confident & $\begin{array}{l}\text { Technical } \\
\text { Non- } \\
\text { technical }\end{array}$ & $\begin{array}{l}379 \\
321\end{array}$ & $\begin{array}{l}3.7447 \\
3.5389\end{array}$ & $\begin{array}{l}1.10956 \\
1.21097\end{array}$ & 698 & 2.344 & 0.019 \\
\hline Allegiance & $\begin{array}{l}\text { Technical } \\
\text { Non- } \\
\text { technical }\end{array}$ & $\begin{array}{l}379 \\
321\end{array}$ & $\begin{array}{l}3.5389 \\
3.2762\end{array}$ & $\begin{array}{l}1.27620 \\
1.33874\end{array}$ & 698 & 2.016 & 0.044 \\
\hline $\begin{array}{l}\text { Financial } \\
\text { Inadequacy }\end{array}$ & $\begin{array}{l}\text { Technical } \\
\text { Non- } \\
\text { technical }\end{array}$ & $\begin{array}{l}379 \\
321\end{array}$ & $\begin{array}{l}3.7318 \\
3.7310\end{array}$ & $\begin{array}{l}1.17733 \\
1.19461\end{array}$ & 698 & 0.008 & 0.994 \\
\hline Risk Aversion & $\begin{array}{l}\text { Technical } \\
\text { Non- } \\
\text { technical }\end{array}$ & $\begin{array}{l}379 \\
321\end{array}$ & $\begin{array}{l}3.5805 \\
3.4907\end{array}$ & $\begin{array}{l}1.29590 \\
1.35897\end{array}$ & 698 & 0.894 & 0.372 \\
\hline Prudence & $\begin{array}{l}\text { Technical } \\
\text { Non- } \\
\text { technical }\end{array}$ & $\begin{array}{l}379 \\
321\end{array}$ & $\begin{array}{l}3.8391 \\
3.9081\end{array}$ & $\begin{array}{l}1.05870 \\
0.96021\end{array}$ & 698 & -0.897 & 0.370 \\
\hline $\begin{array}{l}\text { Self- } \\
\text { responsible }\end{array}$ & $\begin{array}{l}\text { Technical } \\
\text { Non- } \\
\text { technical }\end{array}$ & $\begin{array}{l}379 \\
321\end{array}$ & $\begin{array}{l}4.0950 \\
4.2243\end{array}$ & $\begin{array}{l}1.22429 \\
1.08376\end{array}$ & 698 & -1.467 & 0.143 \\
\hline
\end{tabular}

The above table indicates that $\mathrm{t}$ - test for department with investment behaviour of the respondents.

Department with Perceived Self-Imagery: The t-value is 0.557 , degree of freedom 698 and two-tailed significance is 0.558 . The two-tailed significance for perceived self-imagery indicates that $\mathrm{p}>0.05$ and is not significant. Therefore, we accept the null hypothesis and 
reject the alternative hypothesis. Hence, it is concluded that there is no significant difference between department and perceived self-imagery of the respondents.

Department with Self-confident: The t-value is 2.344, degree of freedom 698 and two-tailed significance is 0.019 . The two-tailed significance for self-confident indicates that $p<0.05$ and is significant. Therefore, we reject the null hypothesis and accept the alternative hypothesis. Hence, it is concluded that there is significant difference between department and selfconfident of the respondents.

Department with Allegiance: The t-value is 2.016, degree of freedom 698 and two-tailed significance is 0.044 . The two-tailed significance for allegiance indicates that $p<0.05$ and is significant. Therefore, we reject the null hypothesis and accept the alternative hypothesis. Hence, it is concluded that there is significant difference between department and allegiance of respondents.

Department with Financial Inadequacy: The t-value is 0.008 , degree of freedom 698 and two-tailed significance is 0.994 . The two-tailed significance for financial inadequacy indicates that $\mathrm{p}>0.05$ and is not significant. Therefore, we accept the null hypothesis and reject the alternative hypothesis. Hence, it is concluded that there is no significant difference between department and financial inadequacies of the respondents.

Department with Risk Aversion: The t-value is 0.894, degree of freedom 698 and two-tailed significance is 0.372 . The two-tailed significance for risk aversion indicates that $p>0.05$ and is not significant. Therefore, we accept the null hypothesis and reject the alternative hypothesis. Hence, it is concluded that there is no significant difference between department and risk aversions of the respondents.

Department with Prudence: The t-value is 0.408 , degree of freedom 698 and two-tailed significance is 0.683 . The two-tailed significance for prudence indicates that $p>0.05$ and is not significant. Therefore, we accept the null hypothesis and reject the alternative hypothesis. Hence, it is concluded that there is no significant difference between department and prudence of the respondents.

Department with Self-responsible: The t-value is -1.467 , degree of freedom 698 and twotailed significance is 0.143 . The two-tailed significance for perceived self-responsible indicates that $\mathrm{p}>0.05$ and is not significant. Therefore, we accept the null hypothesis and reject the alternative hypothesis. Hence, it is concluded that there is no significant difference between department and self-responsible of the respondents.

\subsubsection{Family Type and Investment Decision Behaviour of the Respondents}

To ascertain whether there exists any significant difference in family type with the investment decision behaviour of the respondents the following hypothesis is framed and tested.

Hypothesis 7: There is no significant difference between family type and investment decision behaviour of the respondents

Table 8 Family Type with respect to investment decision behaviour

\begin{tabular}{|l|l|c|c|c|c|c|c|}
\hline \multicolumn{1}{|c|}{ Factors } & \multicolumn{1}{|c|}{$\begin{array}{c}\text { Family } \\
\text { Type }\end{array}$} & $\mathbf{N}$ & Mean & $\begin{array}{c}\text { Std. } \\
\text { Deviation }\end{array}$ & Df & t- value & $\begin{array}{c}\text { Sig. (2- } \\
\text { tailed) }\end{array}$ \\
\hline $\begin{array}{l}\text { Perceived } \\
\text { Self-Imagery }\end{array}$ & Joint & 321 & 2.7858 & 1.38712 & & & \\
& Nuclear & 379 & 2.7170 & 1.35165 & 698 & 0.663 & 0.508 \\
\hline Self-confident & Joint & 321 & 3.6168 & 1.13088 & 698 & -0.703 & 0.482 \\
& Nuclear & 379 & 3.6788 & 1.18643 & & & \\
\hline Allegiance & Joint & 321 & 3.3032 & 1.29212 & 698 & -1.510 & 0.131 \\
\hline
\end{tabular}




\begin{tabular}{|l|l|c|c|c|c|c|c|}
\hline & Nuclear & 379 & 3.4529 & 1.31928 & & & \\
\hline $\begin{array}{l}\text { Financial } \\
\text { Inadequacy }\end{array}$ & Joint & 321 & 3.6781 & 1.19731 & 698 & -1.097 & 0.273 \\
\hline Risk Aversion & Juclear & 379 & 3.7766 & 1.17311 & & & \\
& Noint & 321 & 3.5779 & 1.28884 & 698 & 0.709 & 0.479 \\
\hline Prudence & Joint & 379 & 3.5066 & 1.35570 & & & \\
& Nuclear & 379 & 3.8602 & 1.01391 & 698 & 0.299 & 0.765 \\
\hline $\begin{array}{l}\text { Self- } \\
\text { responsible }\end{array}$ & Joint & 321 & 3.9159 & 1.24590 & 698 & -5.079 & 0.000 \\
\hline
\end{tabular}

The above table indicates that $\mathrm{t}$ - test for family type with investment behaviour of the respondents.

Family Type with Perceived Self-Imagery: The t-value is 0.663 , degree of freedom 698 and two-tailed significance is 0.508 . The two-tailed significance for perceived self-imagery indicates that $\mathrm{p}>0.05$ and is not significant. Therefore, we accept the null hypothesis and reject the alternative hypothesis. Hence, it is concluded that there is no significant difference between family type and perceived self-imagery of the respondents.

Family Type with Self-confident: The t-value is -0.703 , degree of freedom 698 and twotailed significance is 0.482 . The two-tailed significance for self-confident indicates that $\mathrm{p}>0.05$ and is not significant. Therefore, we accept the null hypothesis and reject the alternative hypothesis. Hence, it is concluded that there is no significant difference between family type and self-confident of the respondents.

Family Type with Allegiance: The t-value is -1.510 , degree of freedom 698 and two-tailed significance is 0.134 . The two-tailed significance for allegiance indicates that $p>0.05$ and is not significant. Therefore, we reject the null hypothesis and accept the alternative hypothesis. Hence, it is concluded that there is no significant difference between family type and allegiance of respondents.

Family Type with Financial Inadequacy: The t-value is -1.097, degree of freedom 698 and two-tailed significance is 0.273 . The two-tailed significance for financial inadequacy indicates that $p>0.05$ and is not significant. Therefore, we accept the null hypothesis and reject the alternative hypothesis. Hence, it is concluded that there is no significant difference between family type and financial inadequacies of the respondents.

Family Type with Risk Aversion: The t-value is 0.709 , degree of freedom 698 and twotailed significance is 0.479 . The two-tailed significance for risk aversion indicates that $p>0.05$ and is not significant. Therefore, we accept the null hypothesis and reject the alternative hypothesis. Hence, it is concluded that there is no significant difference between family type and risk aversions of the respondents.

Family Type with Prudence: The t-value is 0.299 , degree of freedom 698 and two-tailed significance is 0.765 . The two-tailed significance for prudence indicates that $p>0.05$ and is not significant. Therefore, we accept the null hypothesis and reject the alternative hypothesis. Hence, it is concluded that there is no significant difference between family type and prudence of the respondents.

Family Type with Self-responsible: The t-value is -5.079 , degree of freedom 698 and twotailed significance is 0.000 . The two-tailed significance for perceived self-responsible indicates that $\mathrm{p}<0.05$ and is significant. Therefore, we reject the null hypothesis and accept 
the alternative hypothesis. Hence, it is concluded that there is significant difference between family type and self-responsible of the respondents.

\section{CONCLUSIONS AND MANAGERIAL IMPLICATIONS OF THE STUDY}

The study had been attempted to identify the dimensions of investment decision behavior and the impact of demographic variables on investment decision behavior. The study identified seven dimensions of investment decision behavior such as perceived self-imagery, selfconfident, allegiance, financial inadequacy, risk aversion, prudence, and self-responsible. Age and designation of the respondents are not related to dimensions of the investment decision behavior. Some investment decision behavior dimensions are having a relationship between income, family size, gender, department, and family type. Financial inadequacy is related to income and family size. Perceived self-imagery, financial inadequacy, and prudence are a relationship with gender. Female is more perceived self-imagery than male. Male are more financial inadequacy than female. Male is more prudence than female. University teachers working in the technical department are more perceived self-imagery, self-confident and allegiance than the non-technical department. The respondents are living in a joint family are more self-responsible than nuclear family members. The results revealed would largely help the practicing managers to understand the dimensions of the investment decision behavior and also impact on demographic variables on investment decision behavior. It would provide a cue to further investment decision behavior.

\section{REFERENCES}

[1] Achar, A., (2012), 'Saving and Investment Behavior of Teachers - An Empirical Study',International Journal of Physical and Social Sciences, ISSN: 2249-5894

[2] Ashok Kumar P., Jagadeshwara M., (1985), 'Demographic Change and Household Savings Behavior in India', Indian Journal of Economics, Vol. 65.

[3] Bal,H.S and Bal.H.K, (1982), 'Farm Family Savings', Yojana, Vol.16, No.20.

[4] Bhatt, K. A. \& Bhatt, K., (2013), ' Effects of Investor Occupation and Education on Choice of Investment: An Empirical Study in India', International Journal of Finance, Vol. 29, No. 4.

[5] Bishnoi, S. (2014), 'Relation between Investment Objective and Demographic Variable', Journal of General Management Research, vol.1, No.1,pp. 91 - 107.

[6] Dhiraj Jain and Parul Jain, (2012), ' Savings and Investment Pattern of School Teachers- A Study with Reference to Udaipur District, Rajasthan', International Journal of Research in Commerce, Economics and Management, Vol.2,No.6.

[7] Fisher J, (1952), 'Income, Spending and Savings patterns of Consumer units in different age groups', Studies in Income and Wealth, vol.15, NEBER, Princeton University Press.

[8] Geetha, N., \& Ramesh, D. M. (2011), 'A Study on People's Preferences in Investment Behaviour', International Journal of Engineering and Management Research (IJEMR), vol.1, No.6.

[9] Geetha, S.N., Vimala, K. ,(2014), ' Perception of household individual investors towards selected financial investment avenues', Procedia Economics and Finance. No. 11, pp 360374.

[10] Graff, M., Tang, K., \& Zhang, J., (2008), 'Demography, Financial Openness, National Savings and External Balance'. 
[11] Jain, D. D., \& Mandot, M. N. (2012), 'Impact of Demographic Factors on Investment Decision of Investors in Rajasthan', Journal of Arts, Science \& Commerce, Vol. III, No. (2(3)), pp. 81 - 92.

[12] Jamshidinavid, B., Chavoshani, M., \& Amiri, S. (2012), 'The Impact of Demographic and Psychological Characteristics on the Investment Prejudices in Tehran Stock', European Journal of Business and Social Sciences, vol.1, No.5,pp. 41 - 53.

[13] Kasilingam and G.Jayabal (2008), 'Segmentation of Investors based on Savings Motivesl' , Indian Journal of Economics and Business, Vol.7, No.2, pp.267-280

[14] Kiran, D., Rao, U.S. (2005), ' Identifying Investor Group Segments Based on Demographic and Psychographic Characteristics', 8th Capital Markets Conference, Indian Institute of Capital Markets Paper, pp. 1-9

[15] Odoemenem, I.U., Ezihe, J.A.C., \& Akerele, S.O., (2013,.' Saving and Investment Pattern of Small - Scale Farmers of Benue State, Nigeria', Global Journal of Human Social Science Sociology\& Culture, ISSN: 2249- 460x

[16] Oyejide, A. T., (1999), ‘ Taking Stock of Sustainable Development Finance in Sub-Saharan Africa'.

[17] Rehman, H., Chaudhry, I. S., Farid, Z. M., \& Bashir, F., (2011), ' Rural-Urban Saving Differentials in Pakistan: Investigation from Primary Data', A Research Journal of South Asian Studies, Vol. 26, No. 1

[18] Schumpeter, J.A., 1934 (2008), 'The Theory of Economic Development: An Inquiry into Profits, Capital, , Interest and the Business Cycle, translated from the German by Redvers Opie, New Brunswick (U.S.A) and London (U.K.): Transaction Publishers.

[19] Sireesha, P.B., \& Laxmi, S., (2013), 'Impact of Demographics on Select Investment Avenues: A Case Study of Twin Cities of Hyderabad and Secunderabad, India', International Journal of Marketing, Financial Services \& Management Research, ISSN 2277- 3622 